DOI: https://doi.org/10.32836/2521-666X/2021-72-5

УДК 334.752:339.944

\author{
Ліпич Л.г. \\ доктор економічних наук, професор, \\ Луцький національний технічний університет
}

\title{
Lipych Liubov
}

Lutsk National Technical University

\section{МОДЕЛІ СТРАТЕГІЧНИХ АЛЬЯНСІВ У КОНТЕКСТІ ЛОГІСТИЧНОГО ПАРТНЕРСТВА \\ MODELS OF STRATEGIC ALLIANCES IN CONTEXT LOGISTICS PARTNERSHIP}

Згідно з логістичним підходом, очікувана спожсивачем цінність полягає у забезпеченні найвищої корисності з погляду часу та місия. Встановлено, щчо джерелом створення конкурентної позииї є диференціація якості обслуговування споживачів, зменшення витрат на логістичні процеси шляхом оптимізащії логістичних потоків продуктів, інформації, капіталу та їх переробки в логістичній системі підприємства або корпоративній мережі. Обтрунтовано, щзо, використовуючи синергію альянсу, підприємства швидко розвиваються завдяки ефективному злиттю знань, навичок, фінансових засобів, технологій, інфраструктури, засобів виробництва. Ідентифіковано моделі стратегічних альянсів логістичного партнерства: тісної інтеграиії, адитивний альянс, комплементарний альянс. У статті наведена логіка створення корисності в моделях стратегічних альянсів логістичного партнерства. Доведено, щзо конкурентні позиції партнерів можна зміцнити за рахунок підвищення якості обслуговування клієнтів, зниження витрат на закупівлю, транспорт, зберігання, упаковку або виконання замовлення.

Ключові слова: стратегічний альянс, логістичне партнерство, альянси, адитивний альянс, альянс тісної інтеграції, комплементарний альянс, логіка створення корисності.

Согласно логистическому подходу, ожидаемая потребителем иенность заключается в обеспечении высокой полезности с точки зрения времени и места. Установлено, что источником создания конкурентной позиции является дифференциация качества обслуживания потребителей, уменьшение затрат на логистические процессы путем оптимизации логистических потоков продуктов, информачии, капитала и их переработки в логистической системе предприятия или корпоративной сети. Обосновано, что, используя синергию альянса, предприятия быстро развиваются благодаря эффективному слиянию знаний, навыков, финансовых средств, технологий, инфраструктуры, средств производства. Идентифицированы модели стратегических альянсов логистического партнерства: тесной интеграции, аддитивный альянс, комплементарный альянс. В статье представлена логика создания полезности в моделях стратегических альянсов логистического партнерства. Доказано, что конкурентные позиции партнеров можно укрепить за счет повышения качества обслужсивания клиентов, снижения затрат на закупку, транспорт, хранение, упаковку или выполнение заказа.

Ключевые слова: стратегический альянс, логистическое партнерство, альянсы, аддитивный альянс, альянс тесной интеграции, комплементарный альянс, логика создания полезности.

From the point of view of the logistical approach, the value expected by the consumer is to provide the highest utility in terms of time and place. Installed that the source of creating a competitive position is the differentiation of customer service quality, reducing the cost of logistics processes by optimizing the logistics flows of products, information, capital and their processing in the logistics system of the enterprise or corporate network. The purpose of the study is to present the benefits of models of strategic alliances of logistics 
partnerships to increase the competitive position of enterprises whose development is based on the internationalization of activities. It is substantiated that using the synergy of the alliance, enterprises develop rapidly due to the effective merger of knowledge, skills, financial resources, technologies, infrastructure, means of production. Models of strategic alliances of logistics partnership are identified. An alliance of close integration is the cooperation of competitors in the field of production of a certain product or the implementation of a certain stage of the production process. It is a partnership of competitors who want to gain at the expense of the alliance: access to joint assets of partners, pooling of investments for innovative projects, achieving benefits through economies of scale, the ability to control the logistics process of competitors with expanded sales channels. An additive alliance is a union of partners who jointly produce and sell the final product $C$. Through this form of cooperation, allies increase their competitive position, which is reflected in increased sales, reduced costs, increased market share and increased barriers to entry into the sector. A complementary alliance brings together competitors who offer complementary services. Most often, one of the partners is involved in the production of product A, the other - in its distribution. Partners strengthen each other's competitive position by improving the quality of customer service, taking into account the increase in the usefulness of time and place in the well-known partner $B$ - the local market. The article presents the logic of creating utility in the models of strategic alliances of logistics partnership.

Key words: strategic alliance, logistics partnership, alliances, additive alliance, close integration alliance, complementary alliance, utility creation logic.

Постановка проблеми. Кожен суб’єкт господарювання, що прагне досягти успіху на цільовому ринку, будує розвиток своєї діяльності на свідомому формуванні цінності, що надає клієнту [1], та на пошуку нових джерел утримання та підвищення своєї конкурентної позиції. Згідно з логістичним підходом, очікувана споживачем цінність полягає у забезпеченні найвищої корисності з погляду часу та місця. Джерелом створення конкурентної позиції є диференціація якості обслуговування споживачів, зменшення витрат на логістичні процеси шляхом оптимізації логістичних потоків продуктів, інформації, капіталу та їх переробки в логістичній системі підприємства або корпоративній мережі. Це означає активізацію діяльності в галузі логістичного партнерства, аутсорсингу, прискорення циклу або інтеграцію та координацію діяльності в ланцюгу поставок. Стратегічні альянси є прикладом реалізації цих завдань у мережі підприємств, пов'язаних із міжнародною діяльністю.

Аналіз останніх досліджень і публікацій. Питання розвитку взаємодії підприємств за типом стратегічних альянсів, що базується на взаємодоповнюваності потенціалів партнерів, досліджувалися в низці робіт зарубіжних авторів: Е. Айєра, Дж. Блейкі, Р. Гріффіна, Б. Гомес-Кассерес, П. Дюсожа, Р.М. Кантера, Д.О. Ніла, М. Пастея, К. Прахелада, Х. Лі Радебі, Л. Саммерса, Г. Хемела, П. Уільямсона та інших. Значний внесок у вирішення проблем створення i функціонування стратегічних альянсів зробили вітчизняні теоретики і практики, такі як М.А. Бобіна, М.В. Гарболінська, Є.Л. Драчова, А.А. Касич, Г.В. Козаченко, А.М. Лібман, В.Д. Маркова, Р.Б. Ноздрьова, С.Е. Пивоваров, А.А. Пилипенко, Л. Шульженко та інші.

Незважаючи на зростаючий інтерес із боку дослідників до проблематики стратегічних альянсів, деякі питання, пов'язані з оцінкою доцільності їх створення, формуванням та функціонуванням, залишаються недостатньо дослідженими.

Метою дослідження є представлення переваг моделей стратегічних альянсів логістичного партнерства для підвищення конкурентної позиції підприємств, розвиток яких базується на інтернаціоналізації діяльності.
Виклад основного матеріалу. Стратегічні альянси, які були відомі ще у XVIII та XIX століттях, набули поширення у глобальній економіці в XX столітті [2], проте лише в останні десятиліття їхня діяльність суттєво активізувалася.

У працях Л. Шульженко стратегічний альянс трактується як «система партнерських гетерархічних відносин, що поєднані різноманітним організаційноправовим забезпеченням суб'єктів господарювання, які мають можливість самостійно та автономно здійснювати свою діяльність як на майнових, так і на немайнових засадах, основною метою яких є ефективне використання ресурсів для досягнення спільних інтересів, єдиних цілей, контролю, розподілу ризиків між учасниками альянсу» [3]. С.Л. Драчова та А.М. Лібман зараховують альянси до нефінансових мегакорпорацій, акцентуючи увагу на тому, що відносини між підприємствами регулюються не акціонерним контролем, а спеціальними угодами [4]. А.А. Пилипенко розглядає їх як «гнучку форму квазіінтерналізації, в межах якої можна нівелювати вплив термінів завершення інтеграційних процесів на користь внесення визначених внесків кожної зі сторін у майбутній розвиток усередині альянсу» [5].

Одним із найбільш поширених визначень сутності стратегічних альянсів підприємств є дефініція, запропонована Б. Гарретом та П. Дюссожем. На думку наведених вище науковців, це «об'єднання задля досягнення спільних інтересів двох або більше незалежних підприємств, що мають на меті створити специфічне виробництво або мають прагнення завершити проект, застосовуючи певні ресурси одне одного, замість того, щоб:

- перемогти конкурентів;

- запустити виробництво самостійно, не розділяючи ні з ким більше ризиків;

- створити умови для злиття або приєднання компаній» [6].

Західні вчені (Б. Гомес-Кассерес, Дж. Блейкі, К. Прахалад, Д. О’Ніл, Г. Хемел, П. Уільямсон) відносять до учасників альянсних утворень виключно ті компанії, які мають ознаки ТНК. Західні економісти, які вже впродовж декількох десятків років досліджу- 
ють розвиток міжнародних стратегічних альянсів, зосереджують свою увагу на вивченні як форм співробітництва, так і систем управління цими структурами. У зарубіжній науці теорія альянсів представлена працями Е. Айера, Р. Гріффіна і М. Пастея [7], Р. Кантера [8] та інших.

Аналізуючи визначення сутності стратегічного альянсу, слід підкреслити, що сучасний стратегічний альянс забезпечує: збереження конкурентних позицій підприємствам, що його утворюють, тих самих переваг, що й концентрація, але водночас не несучи із собою притаманних їй обмежень. Він також передбачає досягнення ефекту масштабу та акумулювання виробничих компетентностей без втрати власної стратегічної автономії та ідентичності партнерів. Стратегічні альянси забезпечують упровадження нових технологій і виступають основою для створення нових видів продукції. Р.Б. Ноздрьова зазначає, що стратегічні альянси мають свою формулу успіху, що складається з таких факторів, як: співпраця партнерів; чіткий сценарій розподілу ролей учасників; основні правила функціонування союзу; оперативність інформаційного обміну; значне охоплення каналів збуту; умови розірвання угоди (або виходу з неї) [9].

Використовуючи синергію альянсу, підприємства швидко розвиваються завдяки ефективному злиттю знань, навичок, фінансових засобів, технологій, інфраструктури, засобів виробництва. Економічні суб'єкти, виходячи 3 вищезазначених переваг та підтримуючи стратегічну та культурну адаптацію потенційних партнерів, мають можливість налагодити співпрацю в межах однієї з шести можливих моделей стратегічних альянсів логістичного партнерства, за варіантами I та II (рис. 1).

Варіант I передбачає співпрацю підприємств у горизонтальній системі, де потенційні партнери ведуть свій бізнес в одній галузі, наприклад, два виробники різних марок автомобілів. Варіант II, навпаки, стосується альянсів, укладених між компаніями, які не конкурують між собою, наприклад постачальники запасних частин та дилери автомобілів (вертикальне розташування).

Оскільки 70\% стратегічних альянсів конкурують між собою, ми зупинимося саме на їх сутнісній характеристиці.

Альянс тісної інтеграції - це співпраця конкурентів у сфері виробництва певного товару або реалізації певної стадії процесу виробництва. Це партнерство конкурентів, які хочуть отримати за рахунок альянсу: доступ до спільних активів партнерів, об'єднання інвестицій для реалізації інноваційних проектів, досягнення переваг за рахунок ефекту масштабу, можливість контролювати логістичний процес конкурента за розширення каналів збуту (рис. 2).

Логістичне партнерство у цьому альянсі, безсумнівно, приносить користь кожному учаснику за рахунок зменшення витрат на здійснення спільних процесів (виробництво, постачання, транспортування, зберігання, пакування чи реалізація замовлень) за рахунок об'єднання ресурсів, набуття нових навичок за одночасного збереження автономності під час реалізації товару А альянсом А та товару В альянсом В. Для прикладу, доцільно розглянути етапи розвитку альянсу «Рено-Ніссан», що являє собою стратегічне франкояпонське партнерство в галузі розвитку машинобудування між компаніями (французькою Renault i японською Nissan), яке було засновано у 1999 році. У жовтні 2016 року Mitsubishi Motors Corporration (MМC) оголосило про те, що Nissan Motor Co., Ltd. (Nissan) завершив придбання 34\% акцій ММС за 237 мільярдів японських ієн і стає найбільшим акціонером компанії MMC $[10 ; 11]$. За підсумками роботи за перше півріч-

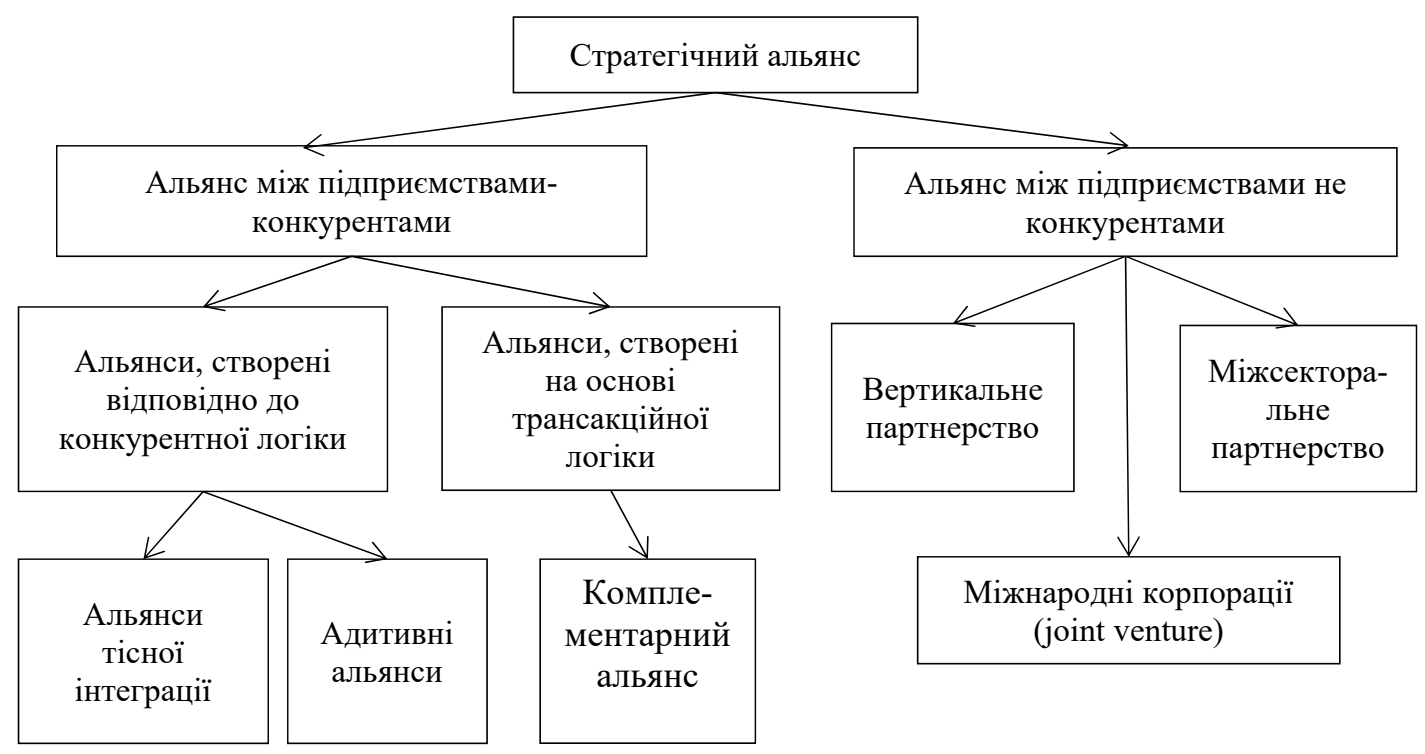

Рис. 1. Види стратегічних альянсів за характером конкурентної поведінки

Джерело: власні напрацювання 


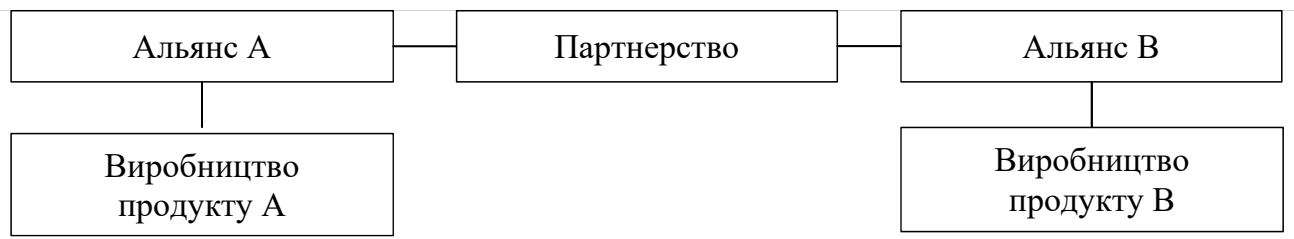

Рис. 2. Альянс тісної інтеграції

Джерело: власні напращювання

чя 2017 року альянс вперше в історії став лідером на світовому ринку автовиробників за кількістю проданих машин. Таким успіхом Renault i Nissan, які володіють великими пакетами акцій один одного, багато в чому зобов'язані приєднанням до альянсу Mitsubishi Motors в 2016 році [12]. Альянс Renault-Nissan-Mitsubishi у 2019 році обігнав за продажами Volkswagen i Toyota і став найбільшим автовиробником у світі, продавши 10,757 млн автомобілів [13].

Адитивний альянс - це союз партнерів, які спільно виробляють і продають кінцевий продукт С. Завдяки такій формі співпраці альянси підвищують конкурентні позиції, що відбивається на збільшенні обсягів продажів, скороченні витрат, збільшенні ринкової частки та підвищенні бар'єрів проникнення в цей сектор (рис. 3).

Вдалим прикладом такої моделі альянсує об'єднання американської American Telephone and Telegraph (ATT) i англійської корпорації British Telecom, що створили організацію, яка займається налагодженням телефонного зв'язку. Територія, де діє нове об'єднання, охоплює близько 200 країн і територій. За оцінками експертів, щорічний оборот об'єднання досягає близько 10 млрд дол. США, а щорічний прибуток становить більше 1 млрд дол. США [14].

Комплементарний альянс об'єднує конкурентів, які пропонують взаємодоповнюючі послуги (рис. 4). Найчастіше один із партнерів бере участь у вироб- ництві товару А, інший - в його розподілі. Партнери зміцнюють конкурентні позиції один одного за рахунок підвищення якості обслуговування споживачів 3 урахуванням збільшення корисності часу і місця, на відомому партнеру В локальному ринку. Прикладом вдалого стратегічного альянсу такого типу $\epsilon$ Coca-Cola i Nestle - у сфері просування холодного чаю Nestea, розробником якого $є$ Nestle, однак реалізація товару відбувається через роздрібну мережу Coca-Cola [14].

Залежно від конкретних економічних умов, у яких працює потенційний партнер, і його позиції на ринку передбачається, що нова вища конкурентна позиція альянсу в межах одного з вищезазначених видів дає змогу: зменшувати критичний обсяг реалізації, проникати на нові ринки та здобувати нові компетентності (рис. 5).

Критична маса реалізації залежить насамперед від розширення регіональної чи міжнародної діяльності. В умовах виходу на географічно новий ринок та боротьби з конкурентами, що працюють на ньому, більш раціональним $є$ прийняття рішення про об'єднання зусиль у партнерстві для боротьби за оптимальну, з погляду альянсів, участь на новому ринку чи зміцнення зусиль під час перемовин щодо участі в місцевому бізнесі. У цьому разі найбільш оптимальним є створення адитивного альянсу, в якому партнери А і В разом ви-

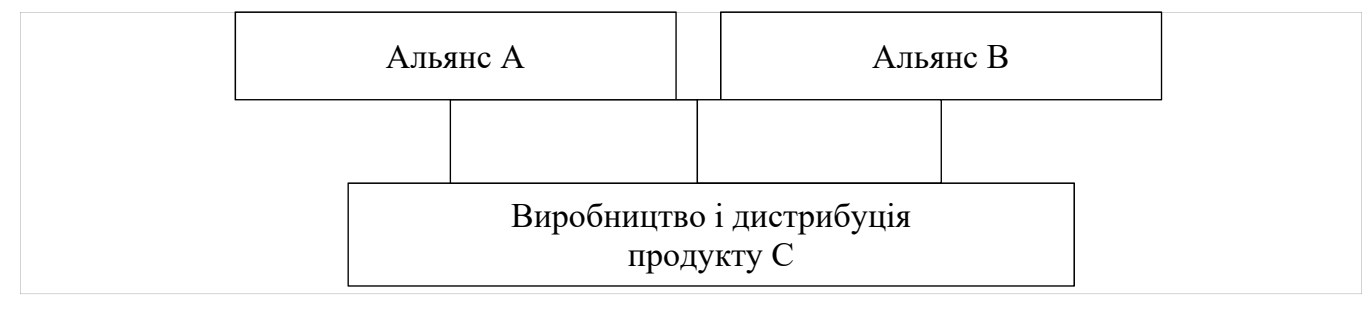

Рис. 3. Адитивний альянс

Джерело: власні напраџюювання

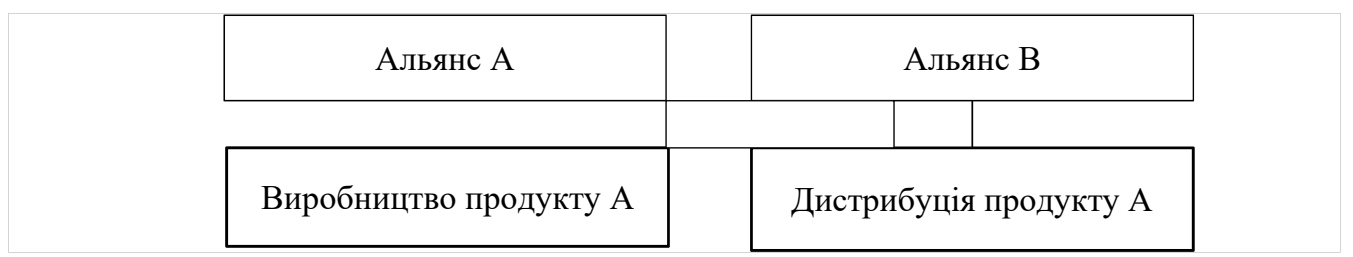

Рис. 4. Комплементарний альянс

Джерело: власні напрачювання 


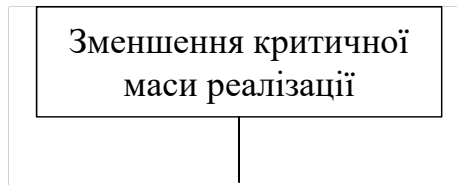

За рахунок об'єднання зусиль

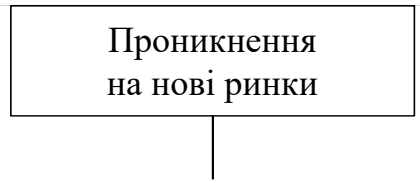

Об'єднання компетентностей

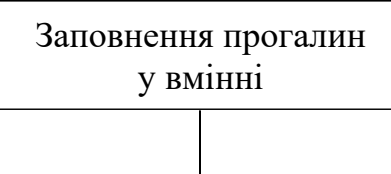

Здобуття

і використання нових знань

Рис. 5. Логіка створення корисності в різних моделях стратегічного альянсу

Джерело: власні напрацювання

робляють та розподіляють кінцевий продукт С на новому ринку. Водночас організаційно-правовою формою цього суб'єкта господарювання є альянс типу «спільне підприємство» (joint venture).

3 погляду об'єднання компетентностей у вибраному виді діяльності в альянсі тісної інтеграції одним із можливих варіантів є створення ефекту операційного важеля шляхом об’єднання ресурсів партнерів. Така співпраця потенційно приводить до посилення конкурентних переваг у вибраній сфері діяльності.

Через збільшення активності суб'єктів господарювання (місцевих, регіональних, національних, міжнародних, глобальних) часто виникає необхідність пошуку місцевих партнерів шляхом створення комплементарного альянсу, в якому альянс А відповідає за виробництво кінцевого продукту А, а партнер В відповідає за його розподіл на внутрішньому ринку. Безсумнівна вигода для партнера А - це заповнення прогалини в знаннях про якість обслуговування, яку очікують отримати споживачів на місцевому ринку партнера В, а також реалізація логістичних потоків у існуючій дистрибуційній мережі альянсу В. 3 іншого боку, з погляду партнера В, комплементарний альянс може бути одним iз можливих способів порятунку місцевого бізнесу, можливістю «залишатися в грі» в контексті зовнішньої агресії конкурентів. У цьому разі юридичною формою підтвердження співпраці між партнерами може бути різновид ліцензійної угоди про франшизу або угоди про співпрацю в конкретній галузі.
Висновок. Ніколи в історії розвитку національних економік не було кращих умов для розширення сфери діяльності підприємств, ніж як із використанням стратегічних альянсів. До основних чинників, що сприяють цим формам розвитку підприємств, належать: простота комунікування, оперативність інформаційного обміну, більш однорідний, стандартизований ринок. Стратегічні альянси - це відповідь у контексті можливості конкурувати на світових ринках. Жодна 3 бізнес-одиниць, діючи самотужки, не може впоратися 3 усіма вимогами міжнародної конкуренції. У цьому контексті зусилля альянсів щодо створення конкурентних переваг на новому ринку можуть включати, з одного боку, отримання доступу до сучасних інновацій, методів організації роботи, технологій маркетингу, а 3 іншого - використання дешевої робочої сили, недорогої виробничої бази і насамперед подолання бар'єрів для проникнення на новий ринок. У будь-якому разі конкурентні позиції партнерів можна зміцнити за рахунок підвищення якості обслуговування клієнтів або зниження витрат на закупівлю, транспорт, зберігання, упаковку або виконання замовлення. Зниження критичної маси реалізації шляхом створення адитивного альянсу дозволяє створити бар'єри для проникнення у цей сектор конкурентів. 3 іншого боку, залучення додаткових ресурсів партнерів в альянсі тісної інтеграції знижує витрати ключових логістичних потоків, тоді як комплементарний альянс $є$ оптимальним рішенням у разі освоєння нового ринку.

\section{Список літератури:}

1. Котлер Ф., Армстронг Г., Сондерс Дж., Вонг В. Основы маркетинга. Кийв : Вильямс. 1999. 1055 с.

2. Касич А.О. Міжнародні стратегічні альянси як чинник розвитку конкурентних переваг підприємства. Економіка та суспільство. 2017. URL: http:/www.economyandsociety.in.ua/ journal/17_ukr/17.pdf (дата звернення: 30.01.2021).

3. Козаченко Г.В., Шульженко Л.С. Стратегічні альянси: дуальний характер. Теоретичні та прикладні питання економіки. 2016. URL: http://tppe.econom.univ.kiev.ua/data/2012_27_1/Zb27_1_07.pdf (дата звернення: 30.01.2021).

4. Драчева Е.Л., Либман А.М. Проблемы определения и классификации интегрированных корпоративных структур. Менеджмент в России и за рубежом. 2001. № 4. С.12-21.

5. Пилипенко А.А. Стратегічна інтеграція підприємств: механізм управління та моделювання розвитку. Харків : «ІНЖЕК». 2008.

6. Гаррет Б., Дюссож П. Стратегические альянсы / пер. с англ. Москва : ИНФРА-М, 2002. 332 с.

7. Гриффин Р., Пастей М. Международный бизнес. Санкт-Петербург. Питер. 2006. 1088 с.

8. Kanter R.M. Collaborative advantage: The art of alliances. Harvard Business Review, 1994. P. 91-108.

9. Ринково-орієнтоване управління інноваційним розвитком. Монографія. Харків : ТОВ «Діса плюс». 2015. $448 \mathrm{c}$.

10. Mitsubishi International Website. URL: http:/www.mitsubishi-motors.com (дата звернення: 30.01.2021). 
11. Nissan International Website. URL: http://www.nissan-global.com (дата звернення: 30.01.2021).

12. Renault International Website. URL: https:/group.renault.com/finance (дата звернення: 30.01.2021).

13. Альянс Renault-Nissan-Mitsubishi вновь стал мировым лидером. URL: https://autoreview.ru/news/al-yansrenault-nissan-mitsubishi-vnov-stal-mirovym-liderom (дата звернення: 30.01.2021).

14. Севостьянова C.I. Міжнародні стратегічні альянси в процесі глобалізації економіки. URL: https://www.sworld.com.ua/ konfer27/828.pdf (дата звернення: 30.01.2021).

\section{References:}

1. Kotler F., Armstrong G., Sonders Dzh., Vong V. (1999) Osnovyi marketinga [Marketing Basics]. Kyiv. Vilyams. 1055 p. (in Russian)

2. Kasich A.O. (2017) Mizhnarodni strateghichni aljjansy jak chynnyk rozvytku konkurentnykh perevagh pidpryjemstva [International strategic alliances as a factor of development of competitive advantages of the enterprise]. Ekonomika ta suspiljstvo [Economy and society]. Available at: http://www.economyandsociety.in.ua/journal/17_ukr/17.pdf (accessed 30 January 2021).

3. Kozachenko G.V., Shulzhenko L.E. (2016) Strateghichni aljjansy: dualjnyj kharakter [Strategic alliances: dual nature]. Teoretychni ta prykladni pytannya ekonomiky [Theoretical and applied issues of economics]. Available at: http://tppe.econom.univ.kiev.ua/data/2012_27_1/Zb27_1_07.pdf (accessed 30 January 2021).

4. Dracheva E.L., Libman A.M. Problemy opredelenyja y klassyfykacyy ynteghryrovannykh korporatyvnykh struktur [Problems of definition and classification of integrated corporate structures]. Moscow: Management in Russia and abroad. (in Russian)

5. Pilipenko A.A. (2008). Strateghichna integhracija pidpryjemstv: mekhanizm upravlinnja ta modeljuvannja rozvyt$\mathrm{ku}$ [Strategic integration of enterprises: the mechanism of management and development modeling]. Kharkyv: INZHEK. (in Ukrainian)

6. Garrett B., Dussozh P. (2002) Strateghycheskye aljjansy [Strategic alliances]. Moscow: Leadership Management. (in Russian)

7. Griffin R., Pastey M. (2006). Mezhdunarodnyiy biznes. [International Business] Sanpetegburg. Piter. 1088 p. (in Russian)

8. Kanter R.M. (1994). Collaborative advantage: The art of alliances. Harvard Business Review. July-August. P. 91-108.

9. Ilyashenko S.M. (2015) Rynkovo-orijentovane upravlinnja innovacijnym rozvytkom: monoghrafija [Marketoriented management of innovative development: monograph]. Kharkiv: Disa pljus.

10. Mitsubishi International Website. Available at: http://www.mitsubishi-motors.com (accessed 30 January 2021).

11. Nissan International Website. Available at: http://www.nissan-global.com (accessed 30 January 2021).

12. Renault International Website. Available at: https://group.renault.com/finance (accessed 30 January 2021).

13. Alyans Renault-Nissan-Mitsubishi vnov stal mirovyim liderom [The Renault-Nissan-Mitsubishi Alliance is once again the world leader]. Available at: https://autoreview.ru/news/al-yans-renault-nissan-mitsubishi-vnov-stal-mirovymliderom (accessed 30 January 2021).

14. Sevostjjanova S.I. (2017) Mizhnarodni strateghichni aljjansy v procesi ghlobalizaciji ekonomiky [International strategic alliances in the process of globalization of the economy] (Electronic journal). Available at: https://www.sworld.com.ua/konfer27/828.pdf (accessed 30 January 2021). 